\title{
Diet and body shape among populations of Bryconamericus iheringii (Otophysi: Characidae) across the Campos Sulinos ecosystem
}

\author{
Érika Endo Kokubun ${ }^{1}$, Karine Orlandi Bonato ${ }^{1}$, \\ Edward D. Burress ${ }^{2}$ and Clarice Bernhardt Fialho ${ }^{1}$
}

\begin{abstract}
Alterations in natural landscapes, mainly caused by anthropic pressures, have been threatening the world's biomes, including aquatic environments and its biota. This study describes the diet of Bryconamericus iheringii, and how its body shape relates to environmental variables in populations of 22 streams. A wide array of food items were found, mainly composed of allochthonous plants (50.5\%) and autochthonous invertebrates (25.2\%). Even though food items remained almost the same, the predominant food group significantly differed among streams, mainly in relation to environmental characteristics. There was variation in body shape primarily associated with body depth and length of the pre-dorsal region; however, these differences did not correspond with streams. PLS-CA analyses indicated that environmental characteristics, such as substrate type, percentage of marginal vegetation have some influence over food items availability but not on body shape. This may be because $B$. iheringii is a non-specialist species capable of prey switching based on availability due to an intermediate body shape suited for generalist feeding habits.
\end{abstract}

Keywords: Ecomorphology, Generalist diet, Grassland ecosystem, Stream.

Alterações em paisagens naturais, principalmente as causadas por pressão antrópica, tem ameaçado os biomas mundiais, incluindo ambientes aquáticos e sua biota. Este estudo descreve a dieta de $B$. iheringii e como seu formato corporal se relaciona com variáveis ambientais, em populações de 22 riachos. Uma grande variedade de itens alimentares foi encontrada, principalmente compostos por plantas alóctones $(50,5 \%)$ e invertebrados autóctones $(25,2 \%)$. Ainda que os itens alimentares tenham permanecido quase os mesmos, o grupo alimentar predominante diferiu significativamente entre riachos, principalmente devido a características ambientais. Ocorreu variação no formato corporal principalmente associado com profundidade do corpo e comprimento da região pré-dorsal; entretanto, tais diferenças não corresponderam aos agrupamentos por riacho. A análise PLS-CA indicou que as características ambientais, tais como tipo de substrato, porcentagem de vegetação marginal exercem alguma influência sobre a disponibilidade dos itens alimentares, mas não sobre o formato corporal. Isso pode ocorrer por B. iheringii ser uma espécie não especialista com capacidade de mudar suas presas de acordo a com disponibilidade das mesmas, isto, devido ao seu formato corporal intermediário adequado a hábitos generalistas.

Palavras-chave: Dieta generalista, Ecomorfologia, Ecossistema de pastagem, Riachos.

\section{Introduction}

Due to great anthropogenic pressure, the world's natural landscapes have been transformed (DeFries et al., 2004; Foley et al., 2005). Land use, for instance, enhances primary production available for human populations but decreases availability for ecosystem processes (DeFries et al., 2004), changes hydrological responses (Costa et al., 2003), causes habitat loss and fragmentation, degradation of soil, and changes the assemblage composition of plants, fish, and birds (Harding et al., 1998; Grau et al., 2003; Waltert et al., 2004). Given that aquatic and terrestrial environments are interdependent (Dufech et al., 2003), activities that affect land cover and its ecological processes may propagate impacts to aquatic environments and their biotic components, including native ichthyofauna (Ferreira, Casatti, 2006). Alterations in physical and chemical properties of terrestrial and aquatic habitats, therefore, can modify characteristics of fish assemblages such as abundance and diversity (Tramer, Rogers, 1973; Dyer et al., 2003; Cunico et al., 2006).

\footnotetext{
'Laboratório de Ictiologia, Instituto de Biociências, Universidade Federal do Rio Grande do Sul, Av. Bento Gonçalves, 9500, Agronomia, 91501-970 Porto Alegre, RS, Brazil. (EEK) erikakokubun@gmail.com, (KOB) kakabio2005@yahoo.com.br, @http://orcid.org/00000002-3741-8086 (corresponding author), (CBF) cbfialho@via-rs.net

${ }^{2}$ Department of Biological Sciences, Auburn University Museum of Natural History, Auburn University, 101 Life Sciences Bldg., Auburn University, 36849 Auburn, AL, USA. edwarddburress@gmail.com
} 
Despite being an endangered biome due to agriculture and silviculture activities, the Campos Sulinos ecosystem is still considered an area with high fish diversity (Pillar, Lange, 2015). Its ichthyofauna extends throughout four drainage systems: the Uruguai River basin, Laguna dos Patos System, part of Paraná State drained by Iguaçú River, and a coastal basin between the states of Rio Grande do Sul and Santa Catarina (MMA, 2000). Yet, our knowledge of its fish fauna is fragmented and scarce in many aspects (i.e., taxonomy, biogeography, ecology, and conservation status). Biological traits are useful tools to increase knowledge and to help understand certain ecological aspects. Feeding biology and morphology, for instance, are good indicators of population dynamics, ecology of species, community structure and help to understand the food web of the system (Polis, Winemiller, 1996).

Even though there can be a certain specificity for certain food items, the majority of fish species have a highly flexible feeding behavior (i.e. trophic plasticity) (Abelha et al., 2001; Meurer, Zaniboni-Filho, 2012), particularly Neotropical freshwater species. This feeding flexibility is an adaptive response (Brandão-Gonçalves et al., 2009) to fluctuations in the availability of food resources in the environment (Abelha et al., 2001). Such fluctuations may be caused by several factors such as physicochemical, spatial and temporal components (Lawlor, 1980; Costa et al., 2013; Jacobson et al., 2015). For example, the presence of riparian vegetation is an important source of food subsidies for fishes (Esteves, Aranha, 1999; Burnett, Reeves, 2006) as well as for shading the water (Pusey, Arthington, 2003). Its absence, therefore, may result in higher levels of insolation and, consequently, increase primary production by facilitating the growth of diatoms and filamentous algae (Allan, 2004). Other possible consequences include a decrease in invertebrate density (Vasconcelos, Melo, 2008). All those alterations, nearby and within the stream, may influence the diet of fishes by favoring opportunist species that are more flexible in their foraging behaviors and preferences (Oliveira, Bennemann, 2005; Bonato et al., 2012).

Morphological characteristics such as general body shape, head length and caudal peduncle aspect ratio may also be influenced by habitat alterations (Langerhans et al., 2003; Neves, Monteiro, 2003; Zúñiga-Vega et al., 2007), given that differences in body shape are often associated with biotic and abiotic habitat characteristiics (Eklöv, Svanbäck, 2006; Costa, Cataudella, 2007; Faradonbe et al., 2015). Morphology may reflect different ecological and behavioral patterns, including foraging characteristics (Svanbäck, Eklöv, 2002; Costa, Cataudella, 2007; Farré et al., 2015). Foraging is strongly related to morphological traits (Mittelbach et al., 1992), because they constrain feeding efficiency and the consumption of food items (Stoner, Livingston, 1984; Ehlinger, 1990; Pouilly et al., 2003). Therefore, environmental characteristics, including habitat degradation, may influence the diet and morphology of species simultaneously.

To study these different factors that act upon the diet of fish species, it is important to have a study area containing several sampling points with different habitat characteristics and degrees of environmental impact. A broad study area, such as the Campos Sulinos, is ideal for comparisons at these ecological scales. Furthermore, the characid Bryconamericus iheringii (Boulenger, 1887) is a good option for this study, since it occurs in a broad geographical area (Laguna dos $\mathrm{Pa}$ tos System, Uruguay River basin and Paraguay River Basin) and in different types of environments including small and big streams as well as shallow and deep lagoons (Casciotta et al., 2002). Bryconamericus iheringii is considered a generalist, with opportunist dietary habits and a high degree of trophic plasticity (Oricolli, Bennemann, 2006; Oosterom et al., 2013), which are favorable characteristics for this study since they may reflect the availability of resources in the environment.

The objective of this study is to describe the diet and morphology of $B$. iheringii across a broad spatial scale to evaluate the influence of different environmental characteristics, such as substrate composition of the streams, percentage of vegetation cover, presence of human interference, etc. Thus, our hypothesis is that the diet and body shape of populations of $B$. iheringii will vary in response to different environmental characteristics across the Campos Sulinos ecosystem.

\section{Material and Methods}

Study area and sampling. According to Pillar, Lange (2015), the Campos Sulinos is a grassland ecosystem found on the three southernmost states of Brazil (Paraná, Santa Catarina and Rio Grande do Sul states), and distributed on two distinct biomes: the Atlantic Forest and Pampa. The grasslands from the Pampa biome extend throughout the Republic of Uruguay and Argentine provinces, from Bahia Blanca, Argentine to Porto Alegre - RS, Brazil, and is dominated by low grass and small shrubs.

For the present study, 22 streams belonging to two drainages (Tab. 1) and distributed in ten municipalities, in Rio Grande do Sul State, were sampled (Fig. 1). These streams are in the Pampa biome, which is distinguished by vegetation composed of grass, creepers, and some trees and bushes close to bodies of water (Pillar et al., 2009). The climate of the area is subtropical, characterized by mild temperatures and rainfall well distributed throughout the year. Soil, in general, is fertile, being frequently used for agriculture (Pillar et al., 2009).

Fish were sampled during October 2013 (in streams of Alegrete (AL), Quaraí (QR) and Soledade (SL) municipalities), November 2013 (in streams of Santo Antônio das Missões (SM) municipality), December 2013 (in streams of Santana da Boa Vista (SV) municipalitiy), January 2014 (in streams of Jaguarão (JG) municipality), February 2014 (in streams of São Gabriel (SG) municipality), March 2014 (in streams of Santiago (ST) and São Pedro do Sul (SS) municipality), April 2014 (in streams of Lavras do Sul (LV) municipality) using backpack electrofishing. Each sampling took place within a 150 meter passage, after the streams' upstream and downstream were blocked with $0.5 \mathrm{~mm}$ nets, preventing fishes from entering and leaving the reach. After being eu- 


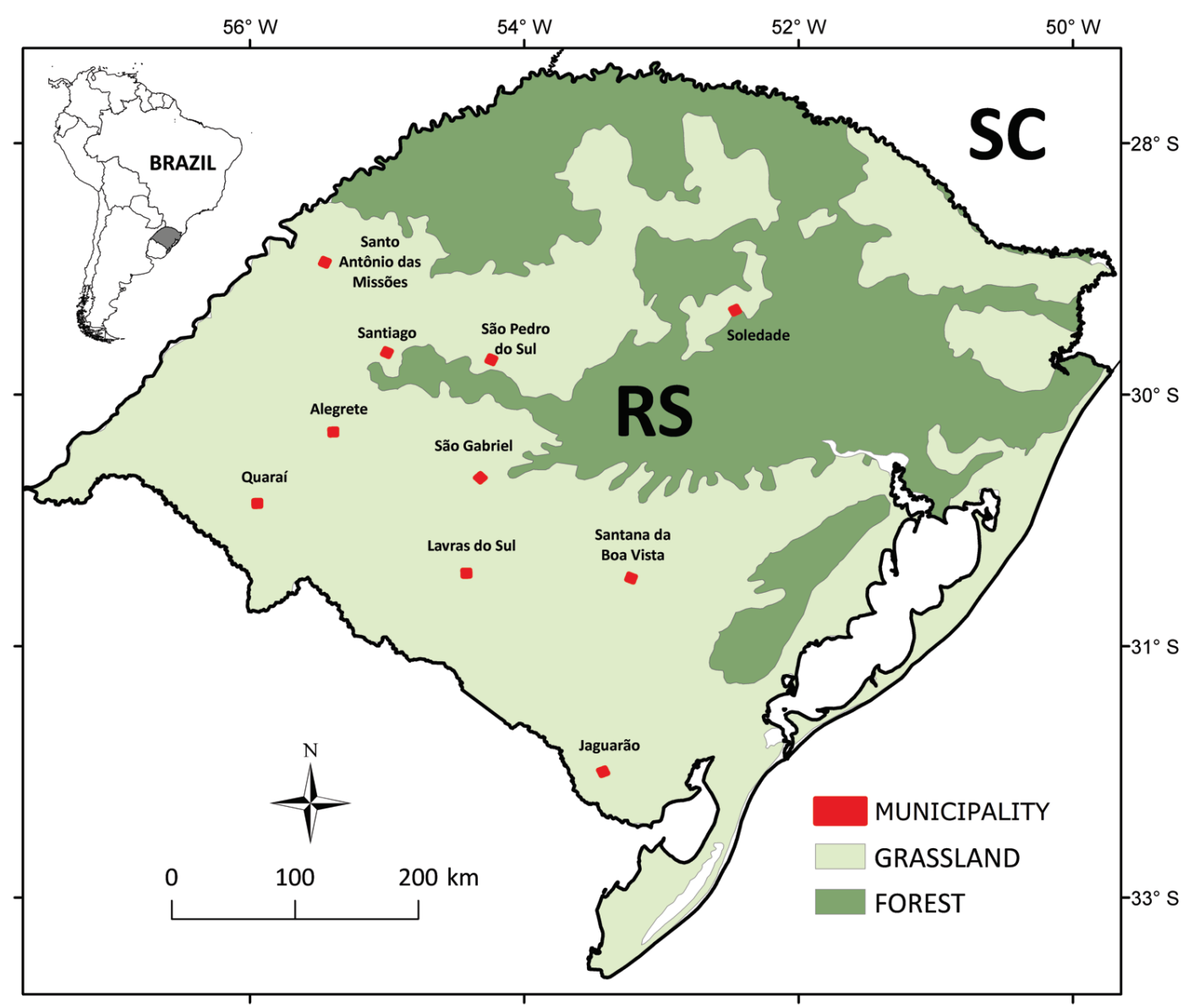

Fig. 1. Location of the ten municipalities in the Rio Grande do Sul State (RS), Brazil, and main land coverage. The landcover map was make with software ArcGIS 10.2 (ESRI, 2013) using the database of Pampa Biome cover of 2009 (UFRGS, 2016).

thanized with 10\% eugenol (Vidal et al., 2008; Lucena et al., 2013), specimens were fixed in 10\% formalin. At the laboratory, fish were preserved in $70 \%$ alcohol, identified with identification keys (Malabarba et al., 2013; Serra et al., 2014) and deposited in the fish collection of the Departamento de Zoologia at the Universidade Federal do Rio Grande do Sul (UFRGS 19238, UFRGS 19243, UFRGS 19246, UFRGS 19249, UFRGS 19254, UFRGS 19299, UFRGS 21339 , UFRGS 21341, UFRGS 23695, UFRGS 21342). In addition, habitat patterns were measured, through previous geographical mapping and habitat characterization from inside the stream and its surroundings according to Kaufmann et al., (1999) (see Dala-Corte et al., 2016a) (Tab. 1, S1 and S2 - available only as online supplementary file accessed with the online version of the article at http:/www.scielo.br/ni).

For the study of feeding characteristics, all adult individuals (standard length bigger than $45 \mathrm{~mm}$ ) per stream were chosen (see Tab. 2 for abundance per stream). Only adults were analyzed in order to avoid ontogenetic influences. All individuals had their total weight (TW) (g) and standard length (SL) (mm) measured. Afterwards, all specimens were eviscerated.

Diet composition and analysis. Stomach contents were analyzed under optical and stereoscopic microscopes. For invertebrates, identifications were made to the lowest taxonomic level possible, using taxonomic keys (Merritt, Cummins, 1996; Costa et al., 2006; Mugnai et al., 2010). Volumes of food items were quantified using graduated test tubes and a glass counting plate (Hellawell, Abel, 1971; Hyslop, 1980). Prey items were pooled into six categories: autochthonous invertebrates (Diptera larvae, Diptera pupae, Trichoptera, Ephemeroptera, Plecoptera, Odonata nymph, aquatic Coleoptera larvae, aquatic Lepidoptera larvae, aquatic adult Hymenoptera, Nematoda, testate amoebae, gastropoda, $\mathrm{Ae}$ gla), autochthonous plants (diatomaceae algae, filamentous algae and aquatic plants), allochthonous invertebrates (adult terrestrial Hymenoptera, adult Diptera, adult Coleoptera, Araneae, etc), allochthonous plants (terrestrial plants), organic matter (scales, unidentified animal and vegetal matter, detritus (all organic matter decomposed)) and inorganic matter (sediment (sand or very small stones)) (Tab. 2).

In order to verify significant differences among streams, we used a Permutational Multivariate Analysis (PERMANOVA) with 9999 permutations (Anderson, 2001; Anderson et al., 2008), based on a Bray-Curtis dissimilarity index (Anderson, 2001). This analysis was performed in $\mathrm{R}$ software (R CoreTeam, 2017) with the Vegan package (Oksanen et al., 2009). 


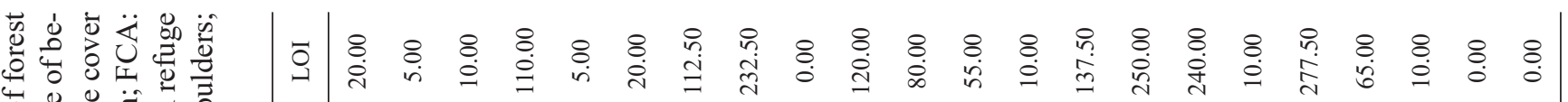

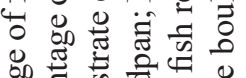

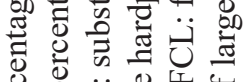

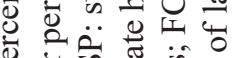

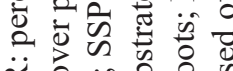

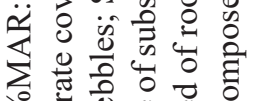

可 00 0

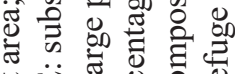

분 흔 है

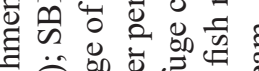

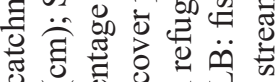

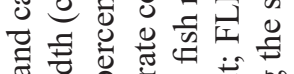

軏

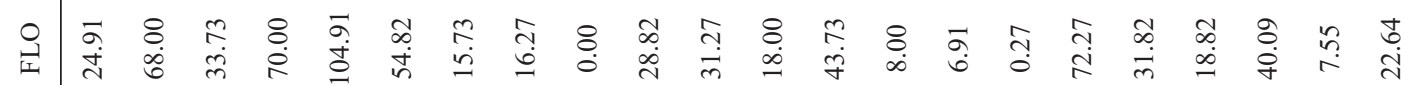

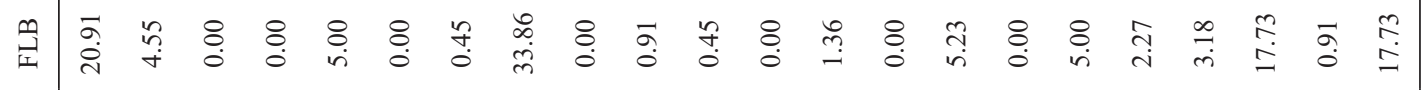

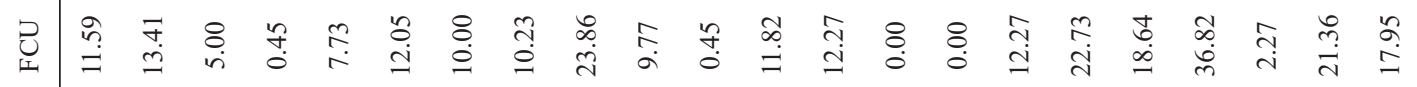

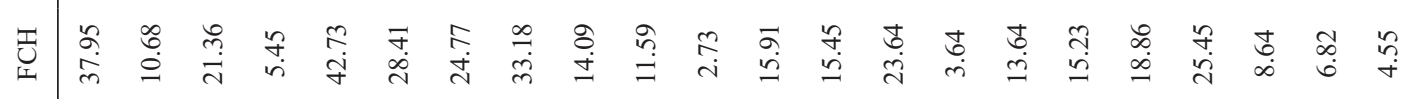

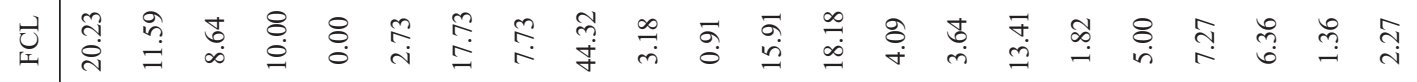

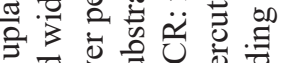

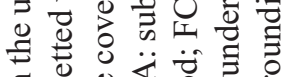

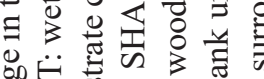

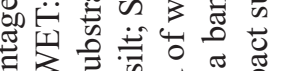

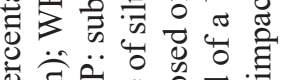

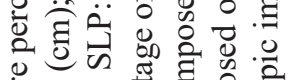

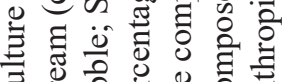
ప 类 نे

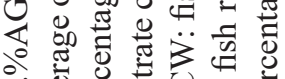

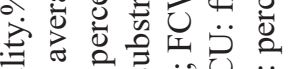

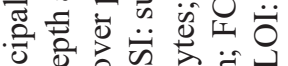

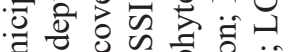

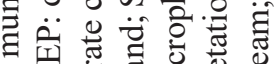

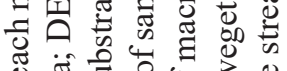
Ð ヨ

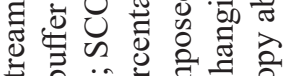
के की

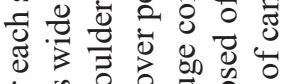

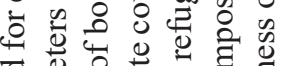

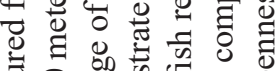

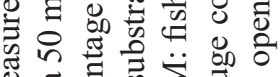

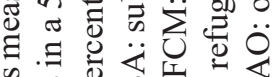

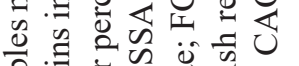
ज्ञ

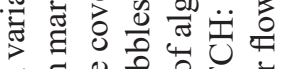

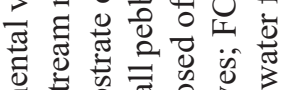

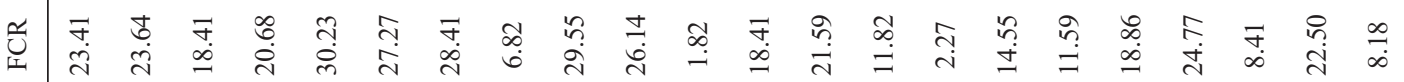

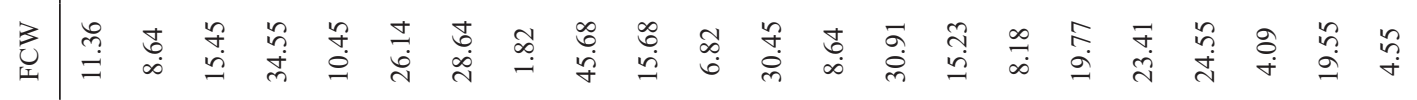

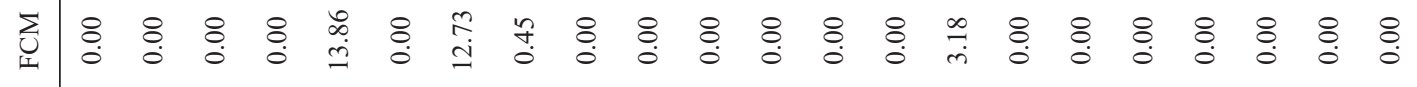
Uు

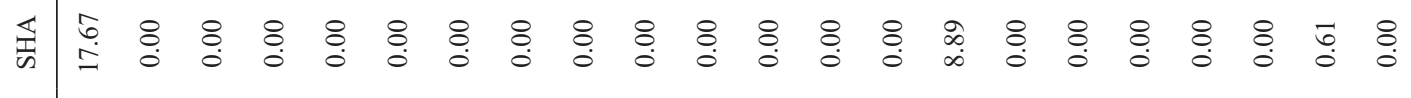

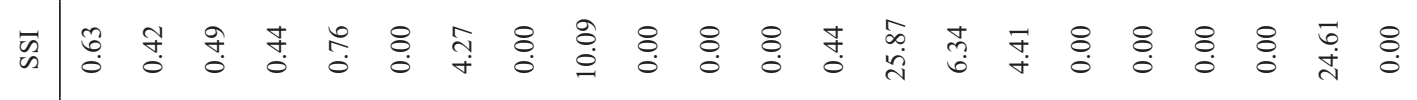

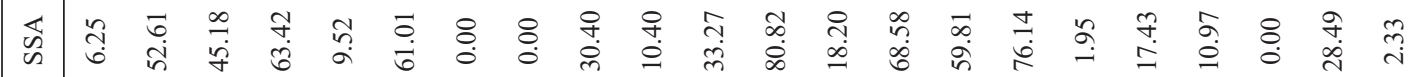

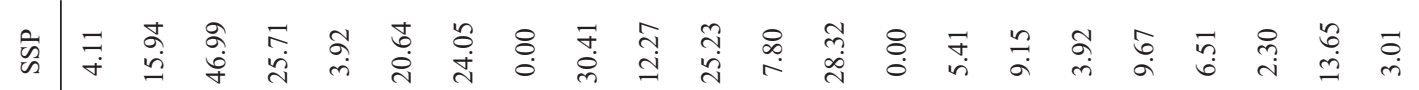

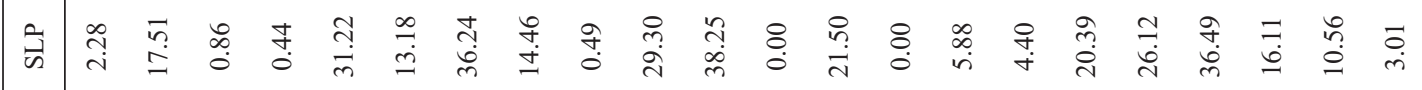

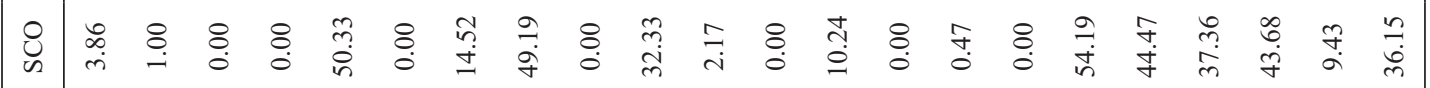

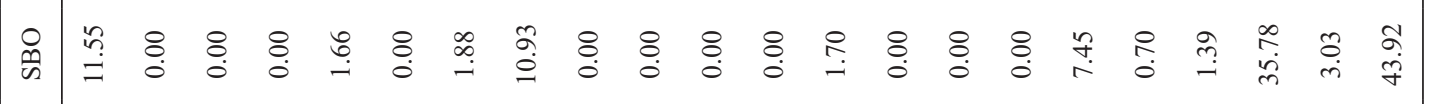

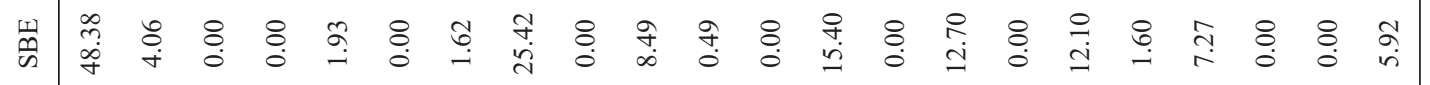

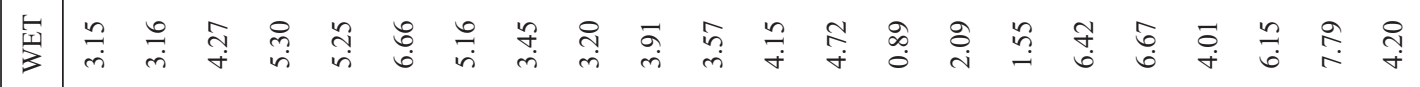

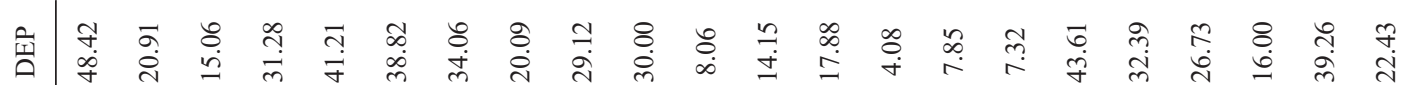

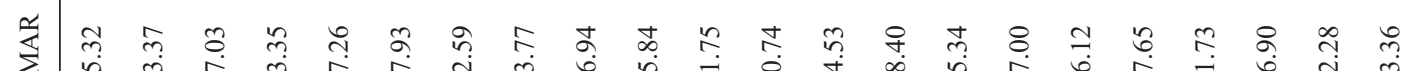

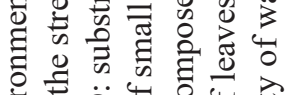
=

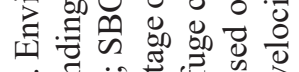

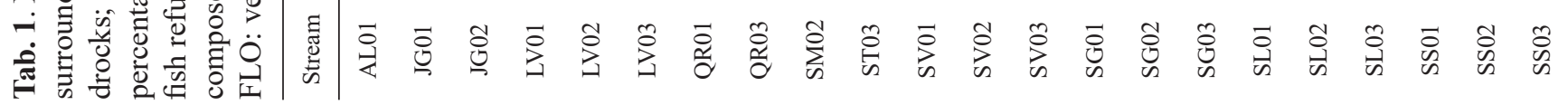

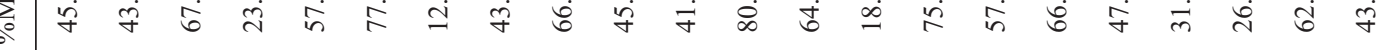

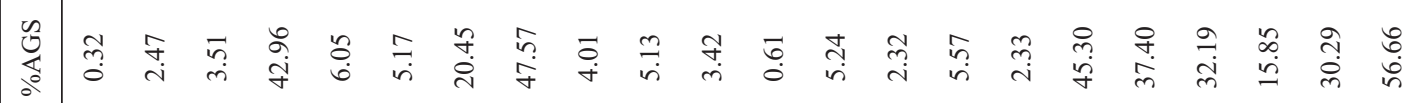


Geometric morphometrics. We quantified the lateral body shape of $B$. iheringii populations among streams using landmark-based geometric morphometrics. For this procedure, the five largest individuals per stream were preserved in ethanol and photographed with a mounted camera (Canon PowerShot SX50 HS). We then used 16 homologous landmarks to quantify lateral body shape (Fig. 2). All analyses were performed in the tps program suite. Photographs were consolidated and landmarked using tpsUtil (Rohlf, 2004) and tpsDIG2 (Rohlf, 2006), respectively. Landmarks were superimposed, aligned and relative warps (RWs) were generated using tpsrelw (Rohlf, 2007). Relative warps are principal components of shape variation. Scale and rotation were removed from the analysis during superimposition and generation of the Procrustes fit.

Modelling. To simultaneously model and visualize the relationships between environmental, dietary, and morphological variables across the 22 streams, we used partial least squares canonical analysis (PLS-CA) (Rohlf, Corti, 2000). For this analysis, the relative proportions of prey items were pooled into the same generalized groups cited before: autochthonous invertebrates, allochthonous invertebrates, autochthonous plants, allochthonous plants, organic matter and inorganic matter. The environmental variables used to modeling were in Tab. 1; first four principal components of body shape; and six major dietary categories. These were coded as blocks of variables and analyzed in a pairwise framework using the PLSCA function in the R package plsdepot (Sanchez, Sanchez, 2012).

\section{Results}

Adults diet composition. Diet of adults consisted of 28 food items. The most consumed groups were allochthonous plants $(50.5 \%)$, followed by autochthonous invertebrates (25.2\%) (Tab. 2). In the autochthonous invertebrates group, the most consumed items were aquatic insect remains, aquatic Lepidoptera larvae, aquatic Coleoptera larvae, Odonata nymphs and Diptera larvae (S3). Based on the PERMANOVA results, there were significant differences in diets among the 22 streams $(\mathrm{F}=22.709, \mathrm{p}=0.001)$. The three streams in Soledade (SL) had a balanced contribution from organic matter and autochthonous items (both invertebrates and plants). The two Quaraí (QR) streams differed between themselves: QR01 had predominance of organic matter followed by higher volumes of autochthonous invertebrates, while QR03 had predominance of both autochthonous and allochthnous plants. The stream from Alegrete (AL), stream from Santo Antônio das Missões (SM) and the three streams

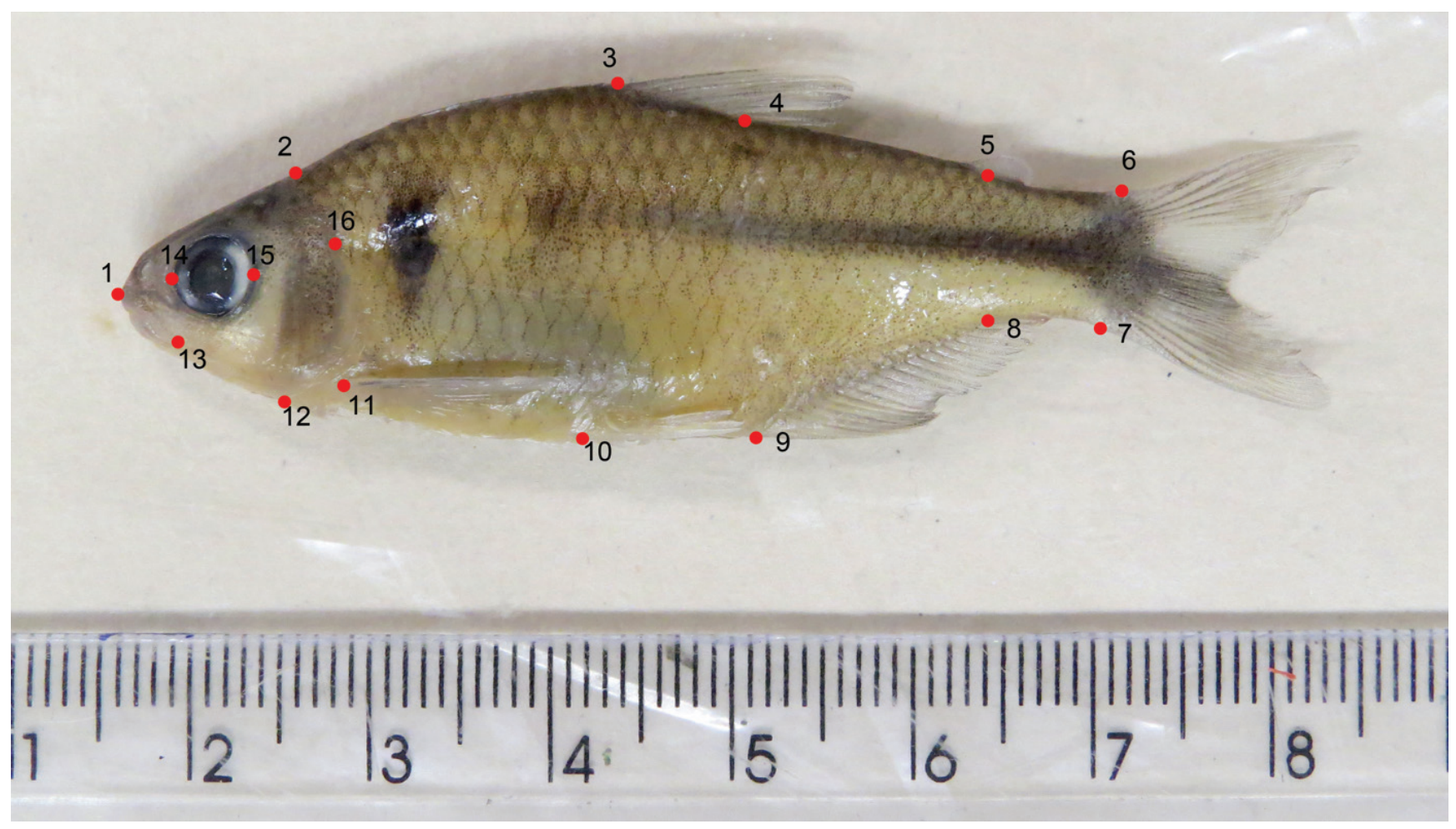

Fig. 2. Individual of Bryconamericus iheringii (UFRGS 21339) with the landmarks used for geometric morphometric. $1=$ Tip of snout; 2 = Top of head (at the supraoccipital bone); $3=$ Anterior insertion of dorsal fin; 4 = Posterior insertion of dorsal fin; $5=$ Posterior insertion of adipose fin; $6=$ Dorsal end of caudal peduncle; $7=$ Ventral end of caudal peduncle; $8=$ Posterior insertion of anal fin; $9=$ Anterior insertion of anal fin; $10=$ Origin of pelvic fin; $11=$ Origin of pectoral fin; $12=$ Ventral end of head; $13=$ Tip of the upper jaw (maxillary bone); $14=$ Anterior margin of eye; $15=$ Posterior margin of eye; $16=$ Anterior margin of opercule. 
Tab. 2. The number of stomachs analyzed (n) and the food groups and their contribution by percentage of volume for the diet of Bryconamericus iheringii in the 22 streams and its respective drainages (Laguna dos Patos System - LP; Uruguay River basin - UR). AUI = autochthonous invertebrates; ALI $=$ allochthonous invertebrates; $\mathrm{AUP}=$ autochthonous plants; $\mathrm{ALP}=$ allochthonous plants; $\mathrm{ORM}=$ organic matter; INM = inorganic matter.

\begin{tabular}{ccccccccc}
\hline Drainage & Stream & AUI & ALI & AUP & ALP & ORM & INM & n \\
\hline LP & SL01 & 1.3 & - & 48.9 & 0.6 & 48.1 & 0.6 & 14 \\
LP & SL02 & 41.8 & 3.9 & 5.2 & 17.2 & 31.7 & - & 14 \\
LP & SL03 & 33.0 & 16.8 & 22.4 & 11.8 & 15.8 & - & 12 \\
UR & QR01 & 24.5 & 3.5 & - & 11.7 & 58.0 & 1.9 & 8 \\
UR & QR03 & 9.6 & - & 54.4 & 28.1 & 7.8 & - & 19 \\
UR & AL01 & 36.0 & 11.1 & 9.0 & 42.8 & - & 0.7 & 10 \\
UR & SM02 & 39.3 & - & - & 59.3 & 1.4 & - & 4 \\
LP & SV01 & 49.9 & 8.9 & - & 31.0 & 9.9 & - & 12 \\
LP & SV02 & 88.4 & 1.0 & - & 2.2 & 7.8 & - & 7 \\
LP & SV03 & 38.8 & 1.9 & - & 53.9 & 5.3 & - & 10 \\
LP & JG01 & 9.9 & 6.1 & - & 58.2 & 25.3 & 0.6 & 10 \\
LP & JG02 & 4.9 & 2.9 & - & 86.7 & 4.7 & 0.8 & 10 \\
UR & ST03 & 14.2 & 4.9 & - & 52.2 & 26.5 & 2.2 & 15 \\
UR & SS01 & 12.1 & 9.9 & - & 73.6 & 4.1 & - & 15 \\
UR & SS02 & 18.4 & 3.5 & 1.4 & 64.8 & 11.5 & - & 10 \\
UR & SS03 & 79.1 & - & - & 17.9 & 2.7 & - & 9 \\
UR & LV01 & 8.6 & 6.7 & - & 74.8 & 9.9 & - & 9 \\
UR & LV02 & 6.5 & 2.3 & - & 90.4 & - & 0.8 & 10 \\
UR & LV03 & 1.0 & - & - & 72.4 & 26.7 & - & 5 \\
LP & SG01 & 31.0 & - & - & 69.0 & - & - & 2 \\
LP & SG02 & 6.6 & - & - & 93.2 & - & - & 10 \\
UR & SG03 & - & - & - & 100.0 & - & - & 2 \\
& Mean(\%) & 25.23 & 3.80 & 6.43 & 50.53 & 13.51 & 0.34 & \\
\hline & & & & & & & &
\end{tabular}

from Santana da Boa Vista (SV) had a high presence of autochthonous invertebrates and allochthonous plants but almost an absence of other groups, when in comparison. Stream SV02 was an outlier in this group, since it had a low presence of allochthonous plants even though it still was very high in autochthonous invertebrates. The three streams of Lavras do Sul (LV), São Gabriel (SG), JG02 from Jaguarão (JG), and SS01 and SS02 from São Pedro do Sul (SS) were characterized by a high contribution of allochthonous plants. SS03 also had a significant presence of autochthonous invertebrates, besides the high volumes of allochthonous plants. JG03 and the stream of Santiago (ST) were characterized by high volumes of allochthonous plants and organic matter.

Geometric morphometrics. Our analyses resulted in four relative warps that described $65.4 \%$ of the variation in body shape. Relative warp 1 explained $28.4 \%$ of the variation and described variation in body depth. Relative warp 2 explained $16.2 \%$ of the variation and described variation in pre-dorsal body length. Relative warp 3 explained 11.4\% of the variation and described variation in the orientation of the mouth and snout. Relative warp 4 explained $9.4 \%$ of the variation and described variation in the length of the head. Individuals from the 22 streams exhibited overlap in morphospace and there was significant overlap among most of the streams. Thus, we calculated the average shape of each stream to facilitate visualization (Fig. 3).

Relative warps describe variation that may be important to ecology and diet, but body shape did not vary among the streams because there were high degrees of shape variation within streams.

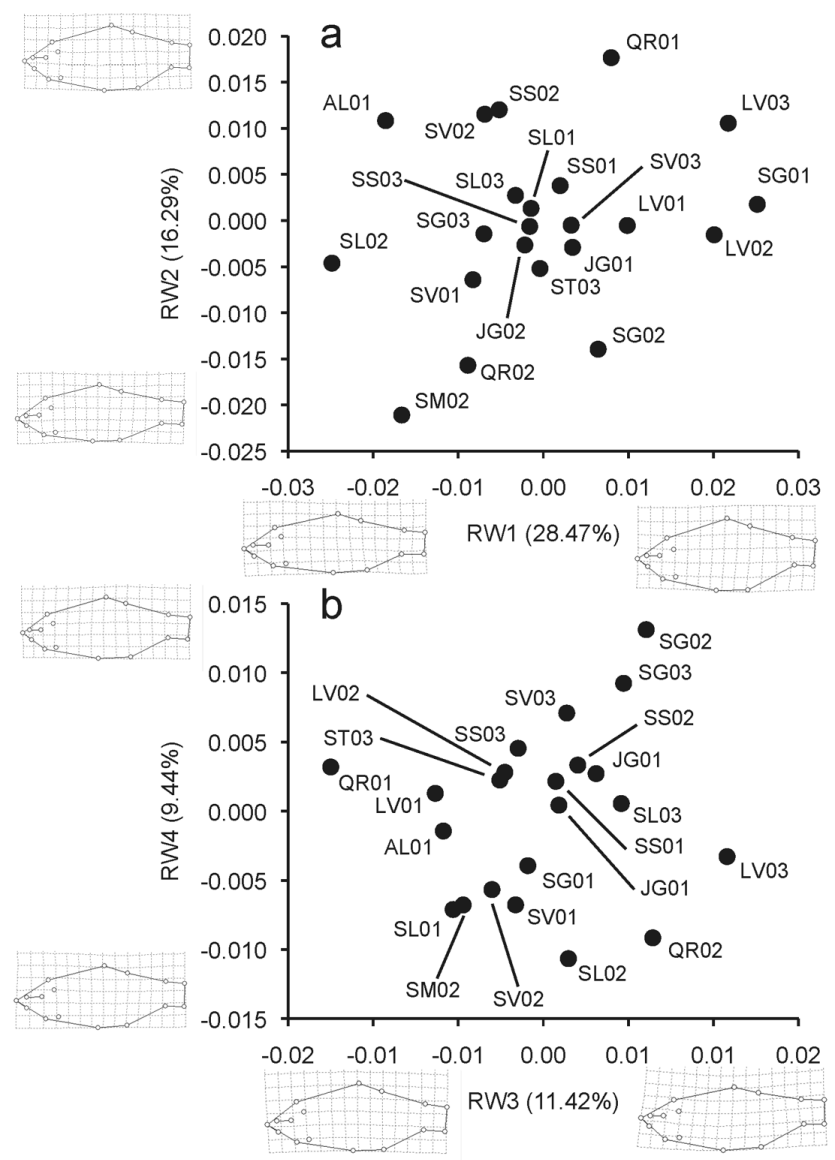

Fig. 3. Relative warps (RW) of body shapes among 22 populations of Bryconamericus iheringii: Alegrete (AL), Jaguarão (JG), Santo Antônio das Missões (SM), São Gabriel (SG), Santiago (ST), São Pedro do Sul (SS), Soledade (SL), Quaraí (QR), Santana da Boa Vista (SV) and Lavras do Sul (LV). Warp transformation grids depict the body shapes associated with the extremes of each axis.

Modelling. Consumption of autochthonous plants was positively correlated with the percentage of agriculture and substrate composed of cobble, boulder and bedrock; but was negatively correlated with substrates composed of sand and pebble, woody cover and canopy openness (Fig. 4a). Consumption of allochthonous plants was positively correlated with substrates composed of sand and pebble, woody cover 
and canopy openness; however, was negatively correlated with the percentage of agriculture and substrate composed of cobble, boulder and bedrock (Fig. 4a).

Additionally, consumption of allochthonous invertebrates, organic matter, and inorganic matter were positively correlated with the presence of macrophytes, root cover, and substrate made of pebbles; and negatively correlated with local impact and the percentage of riparian forest (Fig. 4a). The consumption of autochthonous invertebrates was positively correlated with riparian forest and the presence of leaves (Fig. 4a).
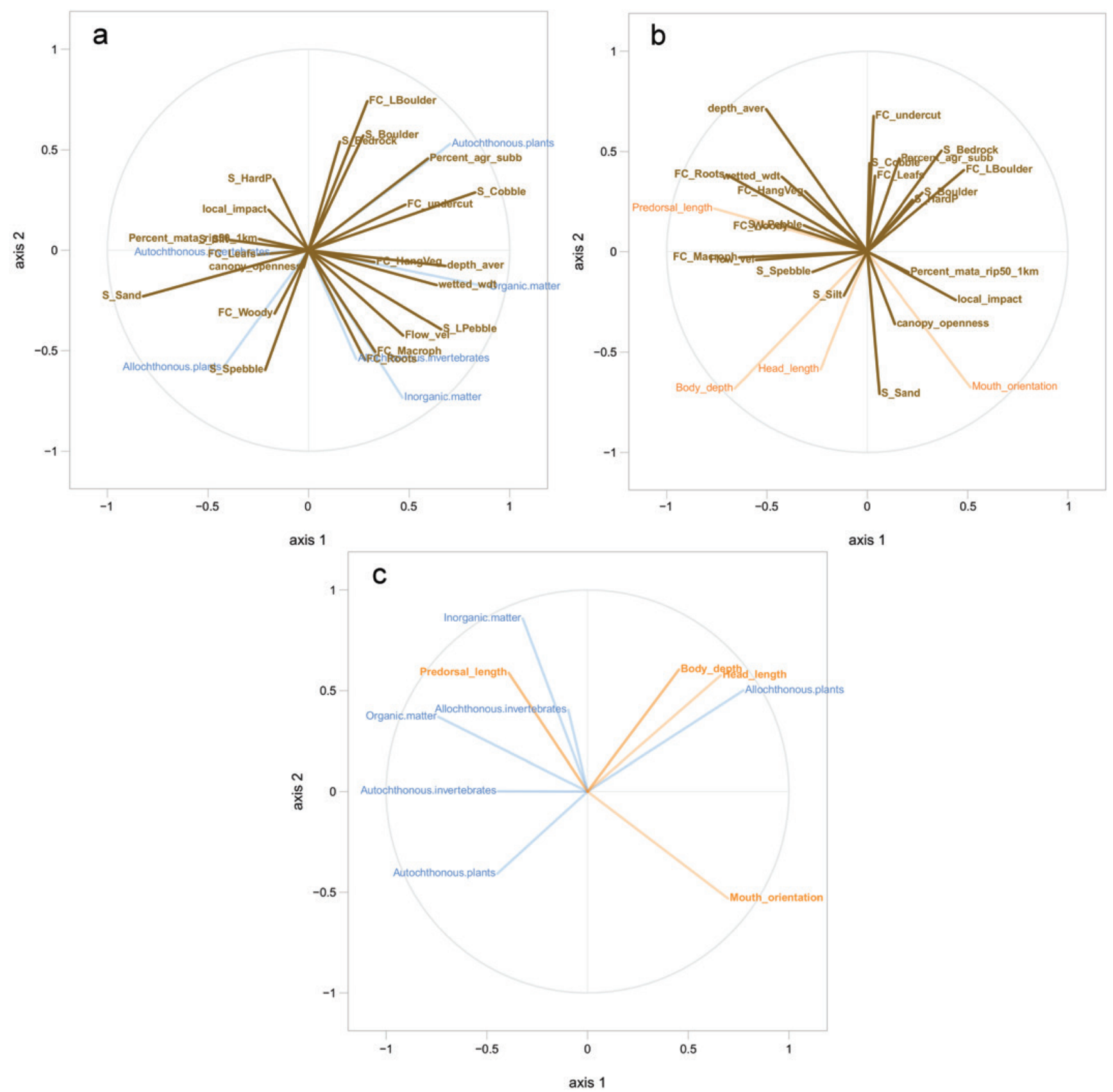

Fig. 4. Partial least squares canonical analysis depicting the covariation between: a. dietary (blue) and environmental (brown) variables; b. morphological (orange) and environmental (brown) variables; c. dietary (blue) and morphological variables (orange). Variables near the edge of the circle are better represented by the model. Variables near one another are positively correlated, whereas variables opposite one another are negatively correlated. Uncorrelated variables are orthogonal. 
found for mouth orientation are possibly not biologically relevant (Fig. 4b).

Lastly, predorsal length was positively correlated with inorganic and organic matter and allochthonous invertebrates (Fig. 4c). Body depth and head length were positively correlated with the consumption of allochthonous plants and negatively with autochthonous plants (Fig. 4c). Mouth orientation was negatively correlated with the major of food groups.

\section{Discussion}

The diet of $B$. iheringii changed between streams that exhibited different environmental characteristics. However, body shape variation did not correspond to populations. In this way, our hypothesis that the diet and body shape of populations of $B$. iheringii will vary in response to different environmental characteristics across the Campos Sulinos ecosystem was not corroborated.

Out of all 22 streams sampled, in 14 (AL01, SM02, SV03, JAG01, JAG02, ST01, SS01, SS02, LV01, LV02, LV03, SG01, SG02, SG03) of them, B. iheringii had a high consumption of allochthonous plants with additional ingestion of autochthonous invertebrates and/or organic matter. All 14 streams have a high percentage of forest surrounding the margins in a 50 meters wide buffer area. In general, riparian forest, when well preserved, allows for more terrestrial resources to enter the streams; therefore, increasing the consumption of allochthonous items such as plants (Pusey, Arthington, 2003; Santos et al., 2015). Moreover, these streams had null values for fish cover composed of algae and macrophytes, which may explain the lower consumption of autochthonous plants.

In the remaining streams (SL01, SL02, SL03, QR01, QR03, SV01, SV02, SS03), the diet of B. iheringii was based on high proportions of autochthonous invertebrates and plants with additional consumption of allochthonous plants and/or organic matter. These sites were also characterized by the presence of rocky substrate (boulders, cobbles or pebbles) and/or fish cover composed of vegetal matter (wood, roots and leaves). These conditions create a structured habitat where invertebrates' larvae can live and proliferate (Wallace et al., 1997). Fallen leaves and other allochthonous items also create a structured habitat by falling inside streams, becoming food items and providing shelter and hideouts where invertebrates' larvae live, which consequently make them an available food item for B. iheringii (Allan et al., 2003; Pusey, Arthington, 2003). Even though higher consumption of autochthonous plants is related with high canopy openness and loss of riparian vegetation (Gregory et al., 1987; Allan, 2004), all streams from SL and stream QR01 presented intermediate values for canopy openness, low of riparian forest and hanging vegetation. It is possible that riverine primary production in all SL streams and in QR01 is higher than terrestrial primary production (Wootton 2012; Burrell et al., 2014), making autochthonous plants a more viable foraging option for fish. Additionally, the two streams of QR and streams SL01 and SL02 were the only sites where organic matter was as significant as the other food groups. Such organic matter could be from riparian forest (terrestrial origin), expressed as woods, leaves and roots as fish cover. It is also possible that in these streams the agriculture percentage is higher and that it contributes to environmental deviations in the aquatic environment, since more organic matter enters streams, which may increase foraging on food items such as detritus (Allan, 2004; Majdi et al., 2015).

Such variation observed in the diet of populations of the same species in aquatic ecosystems is expected in environments with different compositions, as the Neotropical ones (Winemiller, 1990). This variety may be related to indirect interactions (Binning, Chapman, 2010), for instance, intraspecific variation related to morphology or variation in the structure of aquatic ecosystems (Oliveira et al., 2010; Bonato et al., 2017). Therefore, the results found are likely related to both these factors, since $B$. iheringii exhibit a variable diet that changes according to which food items are available in the environment (Oricolli, Bennemann, 2006), as is usual for opportunistic fish (Rezende, Mazzoni, 2003; Ceneviva-Bastos et al., 2010). Opportunistic and/or generalist fish species feed from a wide array of food items and they are also able to change their diet according to food availability (Karr, 1991; Pusey et al., 2010). Accordingly, Rezende, Mazzoni (2003) found that even though B. microcephalus have an insectivorous diet, a few random food items were also consumed, reflecting the trophic plasticity of fish from the Bryconamericus genus in response to food availability in the environment. Nevertheless, B. stramineus have a diet specialized towards insects (Brandão-Gonçalves et al., 2009). As previously discussed, our data showed that in environments with higher percentages of riparian vegetation or with substrate composed by leaf litter, where aquatic insects are found, B. iheringii tend to have an insect-based diet. Accordingly, in environments where macrophytes and algae were abundant, the species had a higher consumption of aquatic plants. Thereby, $B$. iheringii is considered a species that adapts to environmental alterations caused by anthropic impacts, since in the absence of items as insects, it forages on a high volume of detritus and algae (Dala-Corte et al., 2016b).

PLS-CA analysis showed a relationship between diet and environmental variables. It was observed that feeding was related with substrate composition, percentage of forest surrounding the stream margin and composition of fish cover. For example, the percentage of agriculture surrounding streams was found to affect consumption of allochthonous and autochthonous plants. Accordingly, in streams with lower values of agriculture percentage in the upland catchment area, as the case of SL01, SL02 and SL03, there were small contributions of allochthonous plants as opposed to the high proportions of autochthonous plants, autochthonous invertebrates and organic matter. The ingestion of mainly autochthonous invertebrates was correlated with the percentage of riparian forest and, consequently, of fish cover composed 
by leaves (which create a microhabitat for many aquatic insects). This pattern of feeding was observed in streams AL01, SM02, SV01, SV02, SV03 and SS03, where individuals of $B$. iheringii had the highest consumption of autochthonous insects and complemented their diets with allochthonous plants. Thus, the species exhibits different food items for different environmental characteristics. According to Casatti, Castro (2006), species in the Bryconamericus genus are considered active swimmers, thus allowing them to forage throughout the whole water column, but mainly from the substrate and from the surface, on items carried by the current (Ferreira et al., 2012). Furthermore, this capacity to forage on a wide variety of items is also related to the species' morphology.

However, in this study we did not observe a structure of different body shapes among populations, likely due to comparatively high degrees of shape variation within populations. The two major feeding groups, formed by allochthonous plant and autochthonous invertebrate feeders, did not have different body shapes at the population-scale. There may have been minimal selective pressure for differences in body shape, as demonstrated by how similar body shapes were across sites. The food items observed in this study are found on the bottom of streams; thus, even though the predominant food group was not the same for all environments, the items were captured by $B$. iheringii from a similar habitat. Therefore, random phenotypic variation too different and/or far from the generalized shape may not offer high fitness in the majority of these habitats (Travis, 1994). Normally, fish with generalist diets have a more general body shape pattern, located between intermediate values for that specific environment (Faradonbe et al., 2015). Intermediate body shapes differ from specialized body shapes associated with a specific habitat, which can decrease the efficiency of adaptation when habitats are heterogeneous or environmental conditions are unpredictable (Webb, 1984). Therefore, maintaining an intermediate, general body shape should allow for greater ecological flexibility for generalist fish that can utilize a wide array of prey (Wimberger, 1992; Tófoli et al., 2013). Thus, such a generalized body shape probably offered advantages for foraging on a variety of items in streams with minor to large environmental differences.

Despite this low delimitation of specific shape among populations, the PLS-CA analysis showed that correlations between diet and morphology were associated with small variations in the body depth, body and head length, and mouth orientation. The specimens with a deep body and long head length tended to consume allochthonous plants and those with smaller values of those shape dimensions tended to consume items of autochthonous origin. Mouth orientation tends to be more subterminal due to the great consumption of items that are on the bottom, even portions of the allochthonous plants can be foraged from the bottom of the streams. This may be related to a greater efficiency in feeding on items in the middle of the water columns versus from the bottom (Neves, Monteiro, 2003; Pouilly et al.,
2003). Regarding mouth orientation, it tends to be more subterminal when there is a high consumption of items that are in the bottom (Loy et al., 1998; Langerhans et al., 2003), including allochthonous plants in banks of leaves on the bottom of streams. However, as already pointed, the effect of this relationship may be minimal. This pattern may arise due to the fact that feeding characteristics are labile such that they respond quickly to changes in the availability of prey items (Gerking, 1994). However, even if the species have a phenotypic plasticity that allows organisms to change their phenotype in response to shifts in the environment (Parsons et al., 2016), these physical traits still respond more slowly than behavior, such as feeding. Nevertheless, other studies that include a majority of generalist and invertivore or omnivore species found the existence of a relatively weak relationship between diet and morphology (Douglas, Matthews, 1992; Motta et al., 1995; Adite, Winemiller, 1997). In these studies, other factors may have had a major role in determining body shape and trophic guild of the species, such as their phylogenetic relationship or spatiotemporal variables. Therefore, opportunistic and generalist diets are frequently associated with a generalized pattern of body shape (Faradonbe et al., 2015) as shown by the B. ihenringii.

Moreover, many populations of generalists are composed by specialized individuals who feed on certain food groups belonging to the population niche (Araújo et al., 2011). Intrapopulation variation can be caused by variation in resource use that seems to be intrinsic to the individual and has been described as individual specialization (Bolnick et al., 2003). Such variation cannot be attributed to sex, age, environmental factors or how the individual uses the environment (Bolnick et al., 2011). Individual variation can be elicited by several mechanisms such as genetic, phenotypic, environmental where the use of different resources by a single individual is constrained by functional morphology, cognitive ability or digestive ability (Svanbäck, Eklöv, 2003, 2004). The PLS-CA results showed a correlation between morphology and environmental variables, but these are likely weak patterns considering that populations largely overlapped in their body shapes. For example, in the primary body shape axis RW1 (body depth), the streams with more percentage of substrate composed by silt and small pebbles were expected to be in the positive scores. Nevertheless, in LV02 and SG01 there were low proportions of substrate composed by small pebbles and silt, but are located in the positive score area. For populations of Eretmobrycon emperador, body depth also explained the largest variation among the samples (Robert, Hirtle-Lewis, 2012). The authors suppose that variations in body depth could be more related to regional environmental pressures than to other morphology characteristics that seem to vary among the population regardless to samples site. Other studies also found that the measured local habitat characteristics did not explain much about the observed morphological variation (Lostrom et al., 2015), but are related to variation in other factors, such as interactions with environmental and ecological factors. 
There was no strong correlation between diet and morphology with some environmental variables, such as percentage of agriculture and local impact. This is due to the fact that, despite being constantly threatened by soil exploitation, streams still have variable environments. Such variability can highlight the presence of a high proportion of riparian forest surrounding a wide area around the streams. It is known that riparian canopy and nearshore vegetation influence the trophic structure of stream fishes, because they may function as a resource and promote physical heterogeneity of the channel (Zeni, Casatti, 2014). This broad area of riparian forest is what most contributed to a large comsumption of allochthonous plants by $B$. iheringii. However, if land exploration for livestock and soy production keeps rising, bigger morphological and dietary differences may become relevant (Allan, 2004; Dala-Corte et al., 2016b).

The results found in this study indicate that morphology was not strongly correlated with environmental characteristics, while predominant food groups were correlated with only some environmental characteristics. Major axes of body shape (RWs) were correlated with some food items; however, the ecological relevance of such relationships may be limited since morphology seems to differ only slightly among populations. This low variability in morphology may be a reflection of the variety of resources available and the corresponding need to exploit numerous types of resources rather than specialize. An important question that should be addressed in future studies is the apparent individual variation within the populations of $B$. iheringii.

\section{Acknowledgments}

We thank the colleagues of the Ichthyology Lab. and Landscapes Ecology Lab. at the Universidade Federal do Rio Grande do Sul for field work; the Juliano Ferrer and Luiz R. Malabarba for help in identifying the species studied; and Conselho Nacional de Desenvolvimento Científico e Tecnológico (CNPq, Proc. 457403/2012-2, to Ichthyology Lab - L.R. Malabarba) for financial support. Fish samples were collected with authorization \#39672 from register \#873510 from Instituto Brasileiro do Meio Ambiente e dos Recursos Naturais Renováveis (IBAMA). This study was approved by the Ethics Committee on Animal Use of the Universidade Federal do Rio Grande do Sul (Permit \#24434) and was conducted in accordance with protocols in their ethical and methodological aspects, for the use of fish. The committee follows National and International Norms and Guidelines, especially law \#11,794 from 8 November, 2008, which guides the raising and use of animals for educational and research purposes.

\section{References}

Abelha MCF, Agostinho AA, Goulart E. Plasticidade trófica em peixes de água doce. Acta Sci [serial on the Internet]. 2001; 23(2):425-34. Available from: ftp://ftp.nupelia.uem.br/users/ agostinhoaa/publications/105-AC-Abelha-et-al.pdf
Adite A, Winemiller KO. Trophic ecology and ecomorphology of fish assemblages in coastal lakes of Benin, West Africa. Écoscience [serial on the Internet]. 1997; 4(1):6-23. Available from: http://dx.doi.org/10.1080/11956860.1997.11682371

Allan JD, Wipfli MS, Caouette JP, Prussian A, Rodgers J. Influence of streamside vegetation on inputs of terrestrial invertebrates to salmonid food webs. Can J Fish Aquat Sci [serial on the Internet]. 2003; 60(3):309-20. Available from: https://doi. org/10.1139/f03-019

Allan JD. Landscapes and riverscapes: the influence of land use on stream ecosystems. Annu Rev Ecol Evol Syst [serial on the Internet]. 2004; 35:257-84. Available from: https://doi. org/10.1146/annurev.ecolsys.35.120202.110122

Anderson MJ. A new method for non-parametric multivariate analysis of variance. Austral Ecol [serial on the Internet]. 2001; 26(1):32-46. Available from: https://doi.org/10.1111 /j.1442-9993.2001.01070.pp.x

Anderson MJ, Gorley RN, Clarke KR. PERMANOVA+ for PRIMER: Guide to Software and Statistical Methods. England: Plymouth, PRIMER-E; 2008.

Araújo MS, Bolnick DI, Layman CA. The ecological causes of individual specialization. Ecol Lett [serial on the Internet]. 2011; 2011(14):948-58. Available from: https://doi. org/10.1111/j.1461-0248.2011.01662.x

Binning SA, Chapman LJ. Is intraspecific variation in diet and morphology related to environmental gradients? Exploring Liem's paradox in a cichlid fish. Integr Zool [serial on the Internet]. 2010; 5(3):241-55. Available from: https://doi. org/10.1111/j.1749-4877.2010.00209.x

Bolnick DI, Svanbäck R, Fordyce JA, Yang LH, Davis JM, Hulsey $\mathrm{CD}$, Forister ML. The ecology of individuals: incidence and implications of individual specialization. Am Nat [serial on the Internet]. 2003; 161(1):1-28. Available from: https://doi. org/10.1086/343878

Bolnick DL, Amarasekare P, Araújo MS, Bürger R, Levine JM, Novak M, Rudolf VHW, Schreiber SJ, Urban MC, Vasseur DA. Why intraspecific trait variation matters in community ecology. Trends Ecol Evol [serial on the Internet]. 2011; 26(4):183-92. Available from: https://doi.org/10.1016/j.tree.2011.01.009

Bonato KO, Delariva RL, Silva JC. Diet and trophic guild of fish assemblages in two streams with different anthropic impacts in the northwest of Paraná, Brazil. Zoologia [serial on the Internet]. 2012; 29(1):27-38. Available from: http://dx.doi. org/10.1590/S1984-46702012000100004

Bonato KO, Burress ED, Fialho CB. Dietary differentiation in relation to mouth and tooth morphology ofa neotropical characid fish community. Zool Anz [serial on the Internet]. 2017; 267(2017):31-40. Available from: http://dx.doi. org/10.1016/j.jcz.2017.01.003

Brandão-Gonçalves L, Lima-Junior SE, Suarez YR. Feeding habits of Bryconamericus stramineus Eigenmann, 1908 (Characidae), in different streams of Guiraí River Sub-Basin, Mato Grosso do Sul, Brazil. Biota Neotrop [serial on the Internet]. 2009; 9(1):135-43. Available from: http://dx.doi.org/10.1590/S167606032009000100016

Burnett KM, Reeves GH. Comparing riparian and catchment influences on stream habitat in a forested, montane landscape. Am Fish Soc Symp [serial on the Internet]. 2006; 48: 175-97. Available from: https://www.treesearch.fs.fed.us/pubs/29656

Burrell TK, O'Brien JM, Graham SE, Simon KS, Harding JS, McIntosh AR. Riparian shading mitigates stream eutrophication in agricultural catchments. Freshw Sci [serial on the Internet]. 
2014; 33(1):73-84. Available: https://doi.org/10.1086/674180

Casatti L, Castro RMC. Testing the ecomorphological hypothesis in a headwater riffles fish assemblage of the rio São Francisco, southeastern Brazil. Neotrop Ichthyol [serial on the Internet]. 2006; 4(2):203-14. Available from: http://dx.doi.org/10.1590/ S1679-62252006000200006

Casciotta JR, Azpelicueta MDLM, Almirón AE. Bryconamericus uporas sp. nov. (Characiformes, Characidae), a new species from the rio Uruguay basin, in Argentina. Rev Suisse Zool [serial on the Internet]. 2002; 109(1):155-65. Available from: http://naturalis.fcnym.unlp.edu.ar/repositorio/_documentos/ sipcyt/bfa004264.pdf

Ceneviva-Bastos M, Casatti L, Rossa-Feres DC. Meso and microhabitat analysis and feeding habits of small nektonic characins (Teleostei: Characiformes) in Neotropical streams. Zoologia [serial on the Internet]. 2010;27(2):191-200. Available from: http://dx.doi.org/10.1590/S1984-46702010000200006

Costa C, Ide S, Simonka C. Insetos imaturos. Metamorfose e Identificação. Ribeirão Preto/SP: Holos; 2006.

Costa C, Cataudella S. Relationship between shape and trophic ecology of selected species of Sparids of the Caprolace coastal lagoon (Central Tyrrhenian sea). Environ Biol Fish [serial on the Internet]. 2007; 78(2):115-23. Available from: https://doi. org/10.1007/s10641-006-9081-9

Costa MH, Botta A, Cardille JA. Effects of large-scale changes in land cover on the discharge of the Tocantins River, Southeastern Amazonia. J Hydrol [serial on the Internet]. 2003; 283(14):206-17. Available from: http://dx.doi.org/10.1016/S00221694(03)00267-1

Costa MRD, Mattos TM, Borges JL, Araújo FG. Habitat preferences of common native fishes in a tropical river in Southeastern Brazil. Neotrop Ichthyol [serial on the Internet]. 2013; 11(4):871-80. Available from: http://dx.doi.org/10.1590/ S1679-62252013000400015

Cunico AM, Agostinho AA, Latini JD. Influência da urbanização sobre as assembleias de peixes em três córregos de Maringá, Paraná. Rev Bras Zool [serial on the Internet]. 2006; 23(4):1101-10. Available from: https://doi.org/10.1590/S010181752006000400018

Dala-Corte RB, Giam X, Olden JD, Becker FG, Guimarães TF, Melo AS. Revealing the pathways by which agricultural land-use affects stream fish communities in South Brazilian grasslands. Freshw Biol [serial on the Internet]. 2016a; 61(11):1921-34. Available from: https://doi.org/10.1111/fwb.12825

Dala-Corte RB, Becker FG, Melo AS. Riparian integrity affects diet and intestinal length of a generalist fish species. Marine Freshw Res [serial on the Internet]. 2016b; 68(7):1272-81. Available from: http://dx.doi.org/10.1071/MF16167

DeFries RS, Foley JA, Asner GP. Land-use choices: balancing human needs and ecosystem function. Front Ecol Environ [serial on the Internet]. 2004; 2(5):249-57. Available from: https://doi.org/10.1890/1540-9295(2004)002[0249:LCBHNA ]2.0.CO;2

Douglas ME, Matthews WJ. Does morphology predict ecology? Hypothesis testing within a freshwater stream fish assemblage. Oikos [serial on the Internet]. 1992; 65(2):213-24. Available from: https://doi.org/10.2307/3545012

Dufech APS, Azevedo MA, Fialho CB. Comparative dietary analysis of two populations of Mimagoniates rheocharis (Characidae: Glandulocaudinae) from two streams of Southern Brazil. Neotrop Ichthyol [serial on the Internet]. 2003; 1(1):67-74. Available from: http://dx.doi.org/10.1590/S1679-

\section{8}

Dyer SD, Peng C, Mcavoy DC, Fendinger NJ, Masscheleyn P, Castilho LV, Lim JMU. The influence of untreated wastewater to aquatic communities in the Balatuin River, The Philippines. Chemosphere [serial on the Internet]. 2003; 52(1):43-53. Available from: http://dx.doi.org/10.1016/S00456535(03)00269-8

Ehlinger TJ. Habitat choice and phenotype-limited feeding efficiency in bluegill: individual differences and trophic polymorphism. Ecology [serial on the Internet]. 1990; 71(3):886-96. Available from: https://doi.org/10.2307/1937360

Eklöv P, Svanbäck R. Predation risk influences adaptive morphological variation in fish populations. The Am Nat [serial on the Internet]. 2006; 167(3):440-52. Available from: https://doi.org/10.1086/499544

Esteves KE, Aranha JMR. Ecologia trófica de peixes de riachos. Rio de Janeiro: PPGE-UFRJ; 1999. (Série Oecologia Brasiliensis; vol 6).

Environmental Systems Research Institute (ESRI). ArcGIS Desktop 10.2 [Data Analysis Software System]. Redlands: California; 2013.

Faradonbe MZ, Eagderi S, Moradi M. Patterns of body shape variation in Capoeta gracilis (Pisces: Cyprinidae) in relation to environmental variables in Sefidrud River Basin, Iran. JABS [serial on the Internet]. 2015; 9(1):36-42. Available from: www.nobel.gen.tr

Farré M, Lombarte A, Recasens L, Maynou F, Tuset VM. Habitat influence in the morphological diversity of coastal fish assemblages. J Sea Res [serial on the Internet]. 2015; 99:107-17. Available from: http://dx.doi.org/10.1016/j.seares.2015.03.002

Ferreira CP, Casatti L. Integridade biótica de um córrego na bacia do Alto Rio Paraná avaliada por meio da comunidade de peixes. Biota Neotrop [serial on the Internet]. 2006; 6(3):1-25. Available from: http://www.biotaneotropica.org.br/v6n3/pt/ abstract?article+bn00306032006

Ferreira A, Paula FR, Ferraz SFB, Gerhard P, Kashiwaqui EAL, Cyrino JEP, Martinelli LA. Riparian coverage affects diets of characids in neotropical streams. Ecol Freshw Fish [serial on the Internet]. 2012; 21(1):12-22. Available from: https://doi. org/10.1111/j.1600-0633.2011.00518.x

Foley JA, DeFries R, Asner GP, Barford C, Bonan G, Carpenter SR, Chapin FS, Coe MT, Daily GC, Gibbs HK, Helkowski JH, Holloway T, Howard EA, Kucharik CJ, Monfreda C, Patz JA, Prentice IC, Ramankutty N, Snyder PK. Global consequences of land use. Science [serial on the Internet]. 2005; 309(5734):57074. Available from: https://doi.org/10.1126/science.1111772

Gerking SD. Feeding ecology of fish. San Diego: Academic Press; 1994.

Grau HR, Aide TM, Zimmerman JK, Thomlinson JR, Helmer E, Zou X. The ecological consequences of socioeconomic and land-use changes in postagriculture Puerto Rico. BioScience [serial on the Internet]. 2003; 53(12):1159-68. Available from: http://dx.doi.org/10.1641/0006-3568(2003)053[1159:TECOS A]2.0.CO;2

Gregory SV, Lamberti GA, Erman DC, Koski KV, Murphy ML, Sedell JR. Influence of forest practices on aquatic production. In: Salo EO, Cundy TW, editors. Streamside management: forestry and fishery interactions. Seattle/WA: Institute of Forest Resources; 1987. p.233-255. (Contribution 57).

Harding JS, Benfiel EF, Bolstad PV, Helfman GS, Jones EBD. Stream biodiversity: the ghost of land use past. Proc Narl Acad Sci USA. 1998; 95(25):14843-47. 
Hellawell JM, Abel RA. Rapid volumetric method for the analysis of the food of fishes. J Fish Biol [serial on the Internet]. 1971; 3(1): 9-37. Available from: https://doi.org/10.1111/j.1095-8649.1971. tb05903.x

Hyslop EJ. Stomach contents analysis - a review of methods and their application. J. Fish Biol [serial on the Internet]. 1980; 17(4):411-29. Available from: https://doi. org/10.1111/j.1095-8649.1980.tb02775.x

Jacobson B, Grant JWA, Peres-Neto PR. The interaction between the spatial distribution of resource patches and population density: consequences for intraspecific growth and morphology. J Anim Ecol [serial on the Internet]. 2015; 84(4):934-42. Available from: https://doi.org/10.1111/1365-2656.12365

Karr JR. Biological integrity: a long-neglected aspect of water resource management. Ecol Appl [serial on the Internet]. 1991; 1:66-84. Available from: https://doi.org/10.2307/1941848

Kaufmann PR, Levine P, Robison EG, Seeliger C, Peck DV. Quantifying physical habitat in wadeable streams. Washington/ DC: U.S. Environmental Protection Agency; 1999. (EPA/620/R-99/003).

Langerhans RB, Layman CA, Langerhans AK, Dewitt TJ. Habitatassociated morphological divergence in two Neotropical fish species. Biol J Linn Soc [serial on the Internet]. 2003; 80(4):689-98. Available from: https://doi.org/10.1111/j.10958312.2003.00266.x

Lawlor LR. Structure and stability in natural and randomly constructed competitive communities. The Am Nat [serial on the Internet]. 1980; 116(3):394-408. Available from: http:// www.journals.uchicago.edu/doi/abs/10.1086/283634

Lostrom S, Evans JP, Grierson PF, Collin SP, Davies PM, Kelley JL. Linking stream ecology with morphological variability in a native freshwater fish from semi-arid Australia. Ecol Evol [serial on the Internet]. 2015; 5(16):3272-87. Available from: https://doi.org/10.1002/ece3.1590

Loy A, Mariani L, Bertelletti M, Tunesi L. Visualizing allometry: geometric morphometrics in the study of shape changes in the early stages of the two-banded sea bream, Diplodus vulgaris (Perciformes, Sparidae). J Morphol [serial on the Internet]. 1998; 237(2):137-46. Available from: https://doi. org/10.1002/(SICI)1097-4687(199808)237:2<137::AIDJMOR5 $>3.0 . \mathrm{CO} ; 2-\mathrm{Z}$

Lucena CAS, Calegari BB, Pereira EHL, Dallegrave E. O uso de óleo de cravo na eutanásia de peixes. Bol Soc Bras Ictiol [serial on the Internet]. 2013; 105:20-24. Available from: http://www. sbi.bio.br/images/sbi/boletim-docs/2013/marco_105.pdf

Majdi N, Boiché A, Traunspurger W, Lecerf A. Community patterns and ecosystem processes in forested headwater streams along a gradient of riparian canopy openness. FundAM Appl Limnol [serial on the Internet]. 2015; 187(1):63-78. Available from: https://doi.org/10.1127/FAL/2015/0740

Malabarba LR, Neto PC, Bertaco VA, Carvalho TP, Santos JF, Artioli LGS. Guia de identificação dos peixes da bacia do rio Tramandaí. Porto Alegre/RS: Via Sapiens; 2013.

Merritt RM, Cummins KW. An introduction to the aquatic insects of North America. Iowa: Kendall Hunt; 1996.

Meurer S, Zaniboni-Filho E. Reproductive and feeding biology of Acestrorhynchus pantaneiro Menezes, 1992 (Osteichthyes: Acestrorhynchidae) in areas under the influence of dams in the upper Uruguay River, Brazil. Neotrop Ichthyol [serial on the Internet. 2012; 10(1):159-66. Available from: http://dx.doi. org/10.1590/S1679-62252012000100015

Mittelbach GG, Osenberg CW, Wainwright PC. Variation in resource abundance affects diet and feeding morphology in the pumpkinseed sunfish (Lepomis gibbosus). Oecologia [serial on the Internet]. 1992; 90(1):8-13. Available from: https://doi. org/10.1007/BF00317802

MMA-Ministério do Meio Ambiente. Avaliação e ações prioritárias para a conservação da biodiversidade da Mata Atlântica e Campos Sulinos. Brasília/DF: Conservation International do Brasil, Fundação SOS Mata Atlântica, Fundação Biodiversitas, Instituto de Pesquisas Ecológicas, Secretaria de Meio Ambiente do Estado de São Paulo (SEMAD), Instituto Estadual de Florestas/MG; 2000.

Motta PJ, Clifton KB, Hernandez P, Eggold BT. Ecomorphological correlates in ten species of subtropical seagrass fishes: diets and microhabitat utilization. Environ Biol Fishes [serial on the Internet]. 1995; 44:37-60. Available from: https://doi. org/10.1007/978-94-017-1356-6_4

Mugnai R, Nessimian JL, Baptista DF. Manual de identificação de macroinvertebrados aquáticos do Estado do Rio de Janeiro: para atividades técnicas, de ensino e treinamento em programas de avaliação da qualidade ecológica dos ecossistemas lóticos. Rio de Janeiro/RJ: Technical Books; 2010.

Neves FM, Monteiro LR. Body shape and size divergence among populations of Poecilia vivipara in coastal lagoons of southeastern Brazil. J Fish Biol [serial on the Internet]. 2003; 63(4):928-41. Available from: https://doi.org/10.1046/j.10958649.2003.00199.x

Oksanen J, Kindt R, Legendre P, O'Hara B, Simpson GL, Solymos $\mathrm{P}$, Stevens MHH, Wagner H. Vegan: Community Ecology Package [Computer software manual - internet]. R package version 2.5-2; 2009. Available from: http://CRAN.R-project. org/package= vegan

Oliveira DC, Benneman ST. Ictiofauna, recursos alimentares e relações com as interferências antrópicas em um riacho urbano no sul do Brasil. Biota Neotrop [serial on the Internet]. 2005; 5(1):96-107. Available from: http://dx.doi.org/10.1590/S167606032005000100011

Oliveira EF, Goulart E, Breda L, Minte-Vera CV, Paiva LRS, Vismara MR. Ecomorphological patterns of the fish assemblage in a tropical floodplain: effects of trophic spatial and phylogenetic structures. Neotrop Ichthyol [serial on the Internet]. 2010; 8(3):569-86. Available from: https://dx.doi. org/10.1590/S1679-62252010000300002

Oosterom MVL, Ocón CS, Brancolini F, Maroñas ME, Sendra ED, Capítulo RA. Trophic relationships between macroinvertebrates and fish in a pampean lowland stream (Argentina). Iheringia. Sér Zool. 2013; 103(1):57-65. Available from: http://dx.doi. org/10.1590/S0073-47212013000100009

Oricolli MCG, Bennemann ST. Dieta de Bryconamericus iheringii (Ostariophysi: Characidae) em riachos da bacia do rio Tibagi, Estado do Paraná. Acta Sci [serial on the Internet]. 2006; 28(1):59-63. Available from: https://doi.org/10.4025/ actascibiolsci.v28i1.1060

Parsons KJ, Concannon M, Navon D, Wang J, Ea I, Groveas K, Campbell C, Albertson RC. Foraging environment determines the genetic architecture and evolutionary potential of trophic morphology in cichlid fishes. Mol Ecol [serial on the Internet]. 2016; 25(24):6012-23. Available from: https://doi.org/10.1111/ mec. 13801

Pillar VDP, Müller SC, Castilhos ZMDS, Jacques AVA. Campos Sulinos: conservação e uso sustentável da biodiversidade. Brasília/DF: MMA; 2009.

Pillar VPP, Lange O. Os Campos do Sul. Porto Alegre/RS: Rede 
Campos Sulinos-UFRGS; 2015.

Polis GA, Winemiller KO, editors. Food webs: integration of patterns and dynamics. Germany: Springer Science \& Business Media; 1996.

Pouilly M, Lino F, Bretenoux JG, Rosales C. Dietary morphological relationships in a fish assemblage of the Bolivian Amazonian floodplain. J Fish Biol [serial on the internet]. 2003; 62(5):1137-58. Available from: https://doi. org/10.1046/j.1095-8649.2003.00108.x

Pusey BJ, Arthington AH. Importance of the riparian zone to the conservation and management of freshwater fish: a review. Mar Freshw Res [serial on the Internet]. 2003; 54(1):1-16. Available from: http://dx.doi.org/10.1071/MF02041

Pusey BJ, Arthington AH, Stewart-Koster B, Kennard MJ, Read MG. Widespread omnivory and low temporal and spatial variation in the diet of fishes in a hydrologically variable northern Australian river. J Fish Biol [serial on the Internet]. 2010; 77(3):731-53. Available from: https://doi.org/10.1111/ j.1095-8649.2010.02712.x

R Development Core Team. R: A Language and Environment for Statistical Computing [Computer software manual - Internet]. Vienna: RFoundation for Statistical Computing; 2017. Available from: https:/www.r-project.org/

Rezende CF, Mazzoni R. Aspectos da alimentação de Bryconamericus microcephalus (Characiformes, Tetragonopterinae) no córrego Andorinha, Ilha Grande - RJ. Biota Neotrop [serial on the Internet]. 2003; 3(1):1-6. Available from: http://dx.doi. org/10.1590/S1676-06032003000100012

Robert M, Hirtle-Lewis M. Geometric Morphometric Analysis of Bryconamericus emperador and Astyanax aeneus ecomorphs freshwater fish of Eastern Panama. Panama: INDICASATAIP, The Smithsonian Tropical Research Institution; 2012. Available from: http://www.indicasat.org.pa/

Rohlf FJ. tpsUtil [Data Analysis Software System], version 1.44; 2004. Available from: http://life.bio.sunysb.edu

Rohlf FJ. tpsDIG2 [Data Analysis Software System], version 2.1; 2006. Available from: http://life.bio.sunysb.edu

Rohlf FJ. tpsrelw [Data Analysis Software System], version 1.45; 2007. Available from: http://life.bio.sunysb.edu

Rohlf FJ, Corti M. Use of two-block partial least-squares to study covariation in shape. Syst Biol [serial on the Internet]. 2000; 49(4):740-53. Available from: https://doi. org/10.1080/106351500750049806

Sanchez G, Sanchez MG. Package 'plsdepot'. Partial Least Squares (PLS) Data Analysis Methods [Data Analysis Software System], version 0.1 .17 ; 2012. Available from: http://www. plsmodeling.com

Santos FB, Ferreira FC, Esteves KE. Assessing the importance of the riparian zone for stream fish communities in a sugarcane dominated landscape (Piracicaba River Basin, Southeast Brazil). Environ Biol Fish [serial on the Internet]. 2015; 98(8): 1895-912. Available from: https://doi.org/10.1007/s10641015-0406-4

Serra S, Bessort J, Mello FT, Duarte A, Malabarba LR, Loureiro M. Peces del Río Negro. Montevideo: Ministerio de Ganadería, Agricultura y Pesca, Dirección Nacional de Recursos Acuáticos; 2014.

Stoner AW, Livingston RJ. Ontogenetic patterns in diet and feeding morphology in sympatric sparid fishes from seagrass meadows. Copeia [serial on the Internet]. 1984; 1984(1):174-87. Available from: https://www.jstor.org/stable/1445050

Svanbäck R, Eklöv P. Effects of habitat and food resources on morphology and ontongenetic growth trajectories in perch. Oecologia [serial on the Internet]. 2002; 131(1):61-70. Available from: https://doi.org/10.1007/s00442-001-0861-9

Svanbäck R, Eklöv P. Morphology dependent foraging efficiency in perch: a trade-off for ecological specialisation? Oikos [serial on the Internet]. 2003; 102(2):273-84. Available from: https:// doi.org/10.1034/j.1600-0706.2003.12657.x

Svanbäck R, Eklöv P. Morphology in perch affects habitat specific feeding efficiency. Funct Ecol [serial on the Internet]. 2004; 18(4):503-10. Available from: https://doi.org/10.1111/j.02698463.2004.00858.x

Tófoli RM, Alves GHZ, Higuti J, Cunico AM, Hahn NS. Diet and feeding selectivity of a benthivorous fish in streams: responses to the effects of urbanization. J Fish Biol [serial on the Internet]. 2013; 83(1):39-51. Available from: https://doi.org/10.1111/ jfb. 12145

Tramer EJ, Rogers PM. Diversity and longitudinal zonation in fish populations of two streams entering a metropolitan area. Am Midl Nat [serial on the Internet]. 1973; 90(2):366-74. Available from: https://doi.org/10.2307/2424460

Travis J. Evaluating the adaptive role of morphological plasticity. In: Wainwright PC, Reilly SM, editors. Ecological morphology: integrative organismal biology. Chicago: University of Chicago Press; 1994. p.99-122.

UFRGS-IB-Centro de Ecologia. Mapeamento da cobertura vegetal do Bioma Pampa: Ano-base 2009 [Image on the Internet]. 2016 [cited 2018 Aug 1]; Available from: https://www.ufrgs. br/labgeo/index.php/dados-espaciais/245-mapeamento-dacobertura-vegetal-do-bioma-pampa-ano-base-2009

Vasconcelos MC, Melo AS. An experimental test of the effects of inorganic sediment addition on benthic macroinvertebrates of a subtropical stream. Hydrobiologia [serial on the Internet]. 2008; 610(1):321-29. Available from: https://doi.org/10.1007/ s10750-008-9447-4

Vidal LVO, Albinati RCB, Albinati ACL, Lira AD, Almeida TR, Santos GB. Eugenol como anestésico para a tilápia-do-Nilo. Pes Agrop Bras [serial on the Internet]. 2008; 43(8):106974. Available from: http://seer.sct.embrapa.br/index.php/pab/ article/view/498

Wallace JB, Eggert SL, Meyer JL, Webster JR. Multiple trophic levels of a forest stream linked to terrestrial litter inputs. Science [serial on the Internet]. 1997; 277(5322):102-04. Available from: https://doi.org/10.1126/science.277.5322.102

Waltert M, Mardiastuti A, Mühlenberg M. Effects of land use on bird species richness in Sulawesi, Indonesia. Conserv Biol [serial on the Internet]. 2004; 18(5):1339-46. Available from: https://doi.org/10.1111/j.1523-1739.2004.00127.x

Webb PW. Form and function in fish swimming. Sci Am [serial on the Internet]. 1984; 251(1):72-82. Available from: https://www. jstor.org/stable/24969414

Wimberger PH. Plasticity of fish body shape. The effects of diet, development, family and age in two species of Geophagus (Pisces: Cichlidae). Biol J Linn Soc [serial on the Internet]. 1992; 45(3):197-218. Available from: https://doi. org/10.1111/j.1095-8312.1992.tb00640.x

Winemiller KO. Spatial and temporal variation in tropical fish trophic networks. Ecol monog [serial on the Internet]. 1990; 60(3):331-67. Available from: https://doi.org/10.2307/1943061

Wootton JT. River food web response to large-scale riparian zone manipulations. PLoS One [serial on the Internet]. 2012; 7:e51839. Available from: https://doi.org/10.1371/journal. pone. 0051839 
Zeni JO, Casatti L. The influence of habitat homogenization on the trophic structure of fish fauna in tropical streams. Hydrobiologia [serial on the Internet]. 2014; 726(1):259-70. Available from: https://doi.org/10.1007/s10750-013-1772-6

Zúñiga-Vega JJ, Reznick DN, Johnson JB. Habitat predicts reproductive superfetation and body shape in the livebearing fish Poeciliopsis turrubarensis. Oikos [serial on the Internet].
2007; 116(6):995-1005. Available from: https://www.jstor.org/ stable/40235222

\section{(c) (i)}

Submitted April 04, 2017

Accepted July 17, 2018 by Lilian Casatti 